Gadjab Mada International Journal of Business

Vol. 20, No. 3 (Sept.-Dec. 2018): 277-302

\title{
Gold VS Bonds: What Is the Safe Haven for the Indonesian and Malaysian Capital Market?
}

\author{
Robiyanto Robiyanto \\ SatyaWacanaChristianUniversity
}

\begin{abstract}
This study scrutinizes the potency of gold and bonds as safe haven assets for the Indonesian and Malaysian capital markets, because some previous studies have been undertaken in established market settings. The research period for this study was from June 2008 to September 2016. The quantile regression technique was used to analyze the data. The results of this study indicated that gold did not have a role as a safe haven for the Indonesian capital market, but did have a role as the safe haven for the Malaysian capital market. This study also found that Indonesian government bonds, Malaysian government bonds, and Malaysian corporate bonds could not act as safe haven assets. In contrast, corporate bonds in Indonesia had the potency to perform the function of a safe haven for stocks on the Indonesian Stock Exchange.
\end{abstract}

Keywords: gold; hedge; Indonesian corporate bond; Indonesian government bond; Malaysian corporate bond; Malaysian government bond; safe haven

JEL classification: G10

* Corresponding author's e-mail: robiyanto@staff.uksw.edu 


\section{Introduction}

For centuries gold has been used as a universal means of payment, a means to accumulate wealth (Sujit and Kumar 2011; Putra et al. 2018), and as a financial asset (Dee et al. 2013). Wang (2012) also supported this statement by declaring that traditionally, investors view gold as the safest investment instrument (safe haven) especially during a period of recession marked by high inflation risks, a falling exchange rate, and the collapse of the banking sector. This view is not exaggerated, as many experts have proven that gold is the preferred safe haven (Agyei-Ampomah et al. 2013) and a good hedge against inflation (Capie et al. 2005; Tkacz 2007; Worthington and Pahlavani 2007) as well as against political conditions (Ciner et al. 2012) and a turbulent economy (Ciner et al. 2012; Baur and McDermott 2012; Baur and McDermott 2009).

The appeal of gold as a safe haven, or counter-cyclical investment vehicle (Sumner et al. 2010), became worldwide during the global financial crisis of 2008, when stock prices fell, but gold prices survived and even increased, due to the occurrence of capital's flight to safety (AgyeiAmpomah et al. 2013). Roache and Rossi (2010) even found that gold prices have the opposite cyclical movement, which implies that gold can be a safe haven for investors during negative stock market conditions and also when banks collapse (Wang 2012). Tully and Lucey (2007) stated that traditionally, gold could act as a safe haven asset and tends to increase during financial market turmoil. During financial turmoil, investors, in an attempt to secure their assets, will switch to more liquid and qualified assets (Beber et al. 2006; and Robiyanto 2018c).
Various studies on the potential of gold as a safe haven are also rampant after Baur and Lucey (2010) conceptualized safe havens as assets that have no correlation, or are negatively correlated, with other assets or portfolios during turbulent market conditions; hedges as assets that have no correlation, or are negatively correlated, with other assets or portfolios over time; and diversifiers as assets that have a positive and significant correlation with other assets and portfolios over time.

Studies undertaken to assess the potency of gold as a safe haven include those by Ibrahim and Baharom (2012), Ghazali et al. Bahari (2013) and Ibrahim (2012) in the Malaysian capital market, Joy (2011) in the US capital market, Dee et al. (2013) in China's capital market setting, and Faubert (2012) in the international capital markets, including the Brazil, Rusia, India, and China (BRICs). Robiyanto et al. (2017b) studied the hedging effectiveness of precious metals (including gold) in the Indonesian and Malaysian capital markets and found that gold could produce a high hedging effectiveness for both capital markets. Gold could also be a diversifier and enhance the performance of stock portfolios. This has been proven by Ibrahim (2012) in the Malaysian capital market, Ratner and Klein (2008) in the international capital markets, Chua et al. (1990) in the Canadian capital market, Arouri et al. (2014) in China's capital market setting and Kumar (2014) in the Indian capital market.

In addition to gold, bonds have also been found to be a safe haven. A study by Ciner et al. (2012) has proven that, only by using gold, bonds can become a safe haven for stocks. However, most studies still focus on the study of the potency of gold as the single safe haven. In the context of the Indonesian and Malaysian capital markets, 
studies into the potential of gold and bonds as safe havens for those stock markets are still rarely conducted, and possibly have never been done (especially for Indonesia). Based on these reasons, this research scrutinizes the potential of gold and bonds to be safe haven assets for the Indonesian stock market (Indonesia Stock Exchange) and the Malaysian stock market (Kuala Lumpur Stock Exchange). The bonds studied in this research were corporate bonds which could be aggregately represented by S\&P Indonesian Corporate Bond Index (SPICBI) and S\&P Malaysian Corporate Bond Index (MCB); Indonesian government bonds (Government Securities/ SUN) which can be aggregately represented by S\&P Indonesian Government Bond Index (SPIGBI), and Malaysian government bonds represented by S\&P Malaysian Government Bond Index (MGB).

\section{Conceptual Framework}

\section{Asset Class and Safe Haven}

An asset class is a set of assets that have the same fundamental economic burdens and characteristics that make them different to other assets which are not part of their asset class (Greer 1997). This definition is consistent with stocks and bonds, as the asset class for stocks is the growth instrument class, while bonds are classified as fixed income instruments. Other asset classes are cash and the additional asset class, which includes real estate, collectible goods, and derivatives (Baur 2013).

Meanwhile, gold, as a commodity, can be viewed as being in a different asset class because it has a continuous demand [e.g., for investment (Spall 2011)] and because of its ability to function as a hedge (Nastou
2013). According Tully and Lucey (2007), gold is a precious metal classified as a commodity and a monetary asset. Further, gold can be viewed as belonging to different asset classes for it can be an alternative currency, and saved by the main central banks as part of their foreign exchange reserves (Baur 2013).

According to Flavin et al. (2014), a broad definition of a safe haven is an asset with low market risk and high liquidity, used when investors are fearful of market losses. Flavin et al. (2014) also stated that:

"safe haven assets are essentially risk diversifiers that are held to improve the risk-return trade-off of asset portfolios in times of market turbulence."

Similiar to Flavin et al. (2014), Kaul and Sapp (2006) defined a safe haven as being an asset that investors are drawn to in uncertain times. While Baur and Lucey (2010) defined a safe haven more quantitatively, by stating that a safe haven is an asset that has a zero or negative correlation with other assets or portfolios during periods of turmoil in the financial markets.

During turbulence in the capital markets, when the price of other instruments fall, investors will seek to transfer their investments from one asset class to the more qualified and safer asset classes (flight for safety and flight for quality), even for their liquid instruments (flight for liquidity). This action is important so that investors can stop their investment's value from falling (AgyeiAmpomah et al. 2013). One of the instruments used for investment diversion is gold. In recent times, investors generally purchase gold for a hedge and as a safe haven against market turmoil, because gold's price had shown robustness (Robiyanto et al. 2017b). The gold market is always liquid, despite an 
ongoing financial crisis, even when other financial markets suffer from a lack of liquidity. Moreover, gold is a highly liquid precious metal, it can be traded 24 hours a day, and has large denominations with a small spread (Tully and Lucey 2007), and also, gold has the potency of being a better safe haven compared to silver (FiguerolaFerretti and Gonzalo 2010).

A research by Hillier et al. (2006) provided empirical evidence of the role of gold and commodities on the stock market. This result was then confirmed by Baur and McDermott (2009) who conducted a study on gold as a safe haven for several advanced capital markets around the world, including those in the US, Europe, Australia, Canada, Japan, and also in the BRIC (Brazil, Russia, India, and China) countries' capital markets. They both concluded that gold can be a hedge and safe haven for the capital markets. A similar conclusion has also been stated by Marzo and Zagaglia (2010), Baur and Lucey (2010), Faubert (2012), and Jubinski and Lipton (2013). In addition to gold, bonds are also examined for their potential as a safe haven. Although research into the potential of bonds as a safe haven is still relatively limited, a study by Ciner et al. (2012) provides evidence that bonds may become a safe haven, but not a hedge for stocks in the capital markets, when turbulence occurs.

\section{Hypothesis Development}

\section{Gold as a Safe Haven}

Gold is generally viewed as a safe haven for markets, institutions (financial/monetary) and investors (Tomak 2013). According to Coudert and Raymond-Feingold (2011), gold has, historically, always had a role as a medium of exchange in interna- tional monetary exchanges; this makes gold the ultimate safe haven. Therefore, it is not surprising that many researchers try to scrutinize gold's potency as a safe haven. Unfortunately, there is no exact explanation for why gold can act as a safe haven.

According to Baur and Lucey (2010), one explanation is that gold was among the first forms of money and is traditionally perceived as a hedge against inflation. In short, if gold is uncorrelated with other asset classes, those components should contribute significantly to the role of gold (Robiyanto 2018a; Robiyanto et al. 2017a; Robiyanto 2018c; Baur and Lucey 2010), since in the era of globalization, asset classes' correlations increase dramatically. After Baur and Lucey (2010) clearly defined what a safe haven was, many researchers tried to examine whether gold could act as a safe haven asset in many countries. For example, Ciner et al. (2012) found that gold is a robust safe haven for the US capital market during a crisis period, this finding was also supported by Baur and McDermott (2012) and Tomak (2013) who scrutinized the potential role of gold as a safe haven for the Turkish capital market (Istanbul Stock Exchange), and found that gold could act as a safe haven for it. Based on these explanations, some hypotheses are formulated as follows:

\section{H1a: Gold can act as a safe haven for the Indo- nesian capital market \\ H1b: Gold can act as a safe baven for the Ma- laysian capital market}

\section{Bonds as a Safe Haven}

Cappiello et al. (2006) showed that the dynamic conditional correlation between stocks' and bonds' returns usually declined when stock markets get hit by financial crashes. While Maslov and Rochner (2004) 
discovered an interesting fact; during a financial market's crash, the stock prices and spreads moved in opposite directions. This is an indication of the flight to quality phenomenon. In this phenomenon, investors try to switch from stocks to safer asset (i.e., bonds). Therefore, the correlation between the returns from stocks and bonds is typically low, and gets lower during a financial market's crash. Supporting this finding, Christiansen and Ranaldo (2007) showed that the macroeconomic announcements had various significant impacts toward the stocks and bonds' correlation, which depended on the business cycle. They found that macroeconomic announcements' effect on the correlation of the stocks and bonds was highly dependent on those correlations. Zhou (2014) even suggested that investors should shift to bonds when the high-risk regime (i.e., financial turmoil) hit, to secure their investments.

Some researchers [i.e., Krondahl and Lindahl (2012); and Chiang et al. (2013); Flavin et al. (2014)] tried to identify one potential characteristic of bonds as a safe haven. Bonds, as a riskless asset, could be viewed as a safe investment so it was not surprising if bonds could act as a safe haven during an enormous downside in the capital markets. Chiang et al. (2013) found that bonds could act as a safe haven for stocks. This finding was supported by Baur and McDermott (2012) whom found that in a period of uncertainty, bonds could act as a safe haven. Bonds' seniority over stocks also makes bonds serve as a safe haven against severe volatility in the stock markets (Bianconi et al. 2013).

Similar to those studies, Krondahl and Lindahl (2012), by using US treasuries, stated that US treasuries still reign when looking for safe haven instruments. Krondahl and Lindahl (2012) also concluded that US trea- suries are the assets that can act as a perfect safe haven compared to other assets. Outside the US, Bianconi et al. (2013) examined the behavior of stocks and bonds from Brazil, Russia, India and China (BRIC). They found that the return correlation for stocks and bonds in Brazil and Russia are large and negatively significant. Based on that explanation, some further hypotheses are formulated as follows:

H2a: Government bonds can act as a safe haven for the Indonesian capital market

H2b: Government bonds can act as a safe haven for the Malaysian capital market

H3a: Corporate bonds can act as a safe haven for the Indonesian capital market

H3b: Corporate bonds can act as a safe haven for the Malaysian capital market

\section{Methods}

\section{Data}

The data used in this study were from the Composite Stock Price Index (CSPI), the Kuala Lumpur Composite Index (KLCI), S\&P Indonesian Corporate Bond Index (SPICBI), S\&P Indonesian Government Bond Index (SPIGBI), S\&P Malaysian Corporate Bond Index (MCB), and S\&P Malaysian Government Bond Index (MGB), including data of the monthly closing price of gold in Indonesia's local currency (rupiah or IDR), and data of the monthly closing price of gold (Kijang Emas) in Malaysia's local currency (ringgit or MYR), from June 2008 to September 2016. Malaysian Kijang Emas is the official gold bullion coin in Malaysia and is denominated in ringgit. The price of Kijang Emas is determined by the market's prevailing international gold price. This study used the price of a one troy ounce Kijang Emas as a proxy for the gold price in 
Malaysia. Studies by Ibrahim and Baharom (2012); Ibrahim (2012) had also done the same.

The monthly closing data of the CSPI and KLCI were obtained through www.google.com/finance website, while data from the SPICBI, SPIGBI, MCB, and MGB were retrieved through http:// us.spindices. com/indices/fixed-income/. The SPICBI is an index designed to measure corporate bonds' performance in Indonesia, and is denominated in rupiah, while the SPIGBI is an index designed to measure Indonesian government bonds and is also denominated in rupiah. MCB is an index designed to measure corporate bonds' performance in Malaysia and is denominated in ringgit, while the MGB is an index designed to measure the Malaysian government's bonds, and is denominated in ringgit.

The data of gold prices in Indonesia's local currency (GOLDIDR) were acquired by converting world gold prices in US dollars (GOLD) into rupiah by following the exchange rate of the US dollar against the rupiah (USDIDR). The world gold prices and the exchange rate for the US dollar against the rupiah were obtained from Bloomberg. Meanwhile, the Malaysian gold price (one troy ounce of Kijang Emas) annotated as GOLDMYR in this study, was obtained from Bank Negara Malaysia's official website (http://www.bnm.gov.my).

\section{Variables}

The following describes the definitions of the operational variables used in this study. Returns on the Indonesian stock market were calculated from the CSPI's returns by applying this following formula (Robiyanto 2018b):
$R_{C S P I, t}=\left[\frac{C S P I_{t}-\operatorname{CSPI}_{t-1}}{\operatorname{CSPI}_{t-1}}\right]$

where,

$\mathrm{CSPI}_{\mathrm{t}}=$ CSPI's closing price for the Indonesian Stock Exchange at month $t$

$\mathrm{CSPI}_{\mathrm{t}-1}=$ CSPI's closing price for the Indonesian Stock Exchange at month $t-1$

Returns on the Malaysian stock market were calculated from the KLCI's returns by applying this following formula (Robiyanto 2018b):

$R_{K L C I, t}=\left[\frac{K L C I_{t}-K L C I_{t-1}}{K L C I_{t-1}}\right]$

where,

$\mathrm{KLCI}_{\mathrm{t}}=\mathrm{KLCl}^{\prime}$ s closing price for the Kuala Lumpur Stock Exchange at month $t$

$\mathrm{KLCI}_{\mathrm{t}-1}=\mathrm{KLCl}^{\prime}$ s closing price for the Kuala Lumpur Stock Exchange at month $t-1$

Returns on the Indonesian government's bond market were calculated from the return of S\&P Indonesian Government Bond Index (SPIGBI) by applying this following formula:

$R_{S P I G B, t, t}=\left[\frac{S P I G B I_{t}-S P I G B I_{t-1}}{S P I G B I_{t-1}}\right]$

where,

SPIGBI $_{\mathrm{t}}=$ closing price of S\&P Indonesian Government Bond Index at month $t$

SPIGBI $_{\mathrm{t}-1}=$ closing price of S\&P Indonesian Government Bond Index at month $t-1$ 
Returns on the Indonesian corporate bond market were calculated from S\&P Indonesian Corporate Bond Index (SPICBI) by applying this following formula:

$R_{S P I C B I, t}=\left[\frac{S P I C B I_{t}-S P I C B I_{t-1}}{S P I C B I_{t-1}}\right]$

where,

$\mathrm{SPICBI}_{\mathrm{t}}=\mathrm{S} \& \mathrm{P}$ Indonesian Corporate Bond Index's closing price at month $t$

$\mathrm{SPICBI}_{\mathrm{t}-1}=\mathrm{S} \& \mathrm{P}$ Indonesian Corporate Bond Index's closing price at month $t-1$

Returns on the Malaysian govern-ment's bond market were calculated from the return of S\&P Malaysian Government Bond Index (MGB) by applying this following formula:

$R_{M G B, t}=\left[\frac{M G B_{t}-M G B_{t-1}}{M G B_{t-1}}\right]$

where,

$\mathrm{MGB}_{\mathrm{t}}=$ closing price of S\&P Malaysian Government Bond Index at month $t$

$\mathrm{MGB}_{\mathrm{t}-1}=$ closing price of S\&P Malaysian Government Bond Index at month $t-1$

Returns on the Malaysian corporate bond market were calculated from S\&P Malaysian Corporate Bond Index (MCB) by applying this following formula:

$R_{M C B, t}=\left[\frac{M C B_{t}-M C B_{t-1}}{M C B_{t-1}}\right]$

where,

$\mathrm{MCB}_{\mathrm{t}}=\mathrm{S} \& \mathrm{P}$ Malaysian Corporate Bond Index's closing price at month $t$

$\mathrm{MCB}_{\mathrm{t}-1}=\mathrm{S} \& \mathrm{P}$ Malaysian Corporate Bond Index's closing price at month $t-1$
Return on gold per gram in rupiah (GOLDIDR) was calculated from GOLDIDR which was counted by converting the world gold price per troy ounce in US dollars (GOLD) into rupiah per gram by following the US dollar exchange rate against the rupiah (USDIDR). The calculation was done as follows:

GOLDIDR $_{t}=\left(\right.$ GOLD $_{t} *$ USDIDR $\left._{\mathrm{t}}\right) /$

\subsection{3}

Thus, the return on gold per gram in rupiah (GOLDIDR) was calculated by applying this following formula (Robiyanto, Wahyudi, and Pangestuti 2017b):

$R_{G O L D I D R, t}=\left[\frac{G O L D I D R_{t}-G O L D I D R_{t-1}}{G O L D I D R_{t-1}}\right]$

where,

GOLDIDR $_{t}=$ the closing price of gold per gram in rupiah at month $t$

GOLDIDR $_{t-1}=$ the closing price of gold per gram in rupiah at month $t-1$

Return of one troy ounce of Kijang Emas in ringgit (GOLDMYR) was calculated by applying this following formula (Ibrahim and Baharom 2012):

$R_{G O L D M Y R, t}=\left[\frac{G O L D M Y R_{t}-G O L D M Y R_{t-1}}{G O L D M Y R_{t-1}}\right]$

where,

GOLDMYR $_{\mathrm{t}}=$ the closing price of Kijang Emas at month $t$ GOLDMYR $_{\mathrm{t}-1}=$ the closing price of Kijang Emas at month $t-1$

\section{Technique of Analysis}

This study used the Ordinary Least Square (OLS) analysis technique as a cohort 
test to see the potency of gold and bonds as hedging instruments. This OLS analysis was applied by using all the data periods.

The OLS equation used is as follows:

$\mathrm{R}_{\text {Instrument }, \mathrm{t}}=\alpha+\beta_{1} \mathrm{R}_{\text {Index }}+\varepsilon_{\mathrm{t}}$

with

$\varepsilon_{\mathrm{t}} \quad=$ residual term

$\mathrm{R}_{\text {Instrument,t }}=$ return on GOLDIDR, GOLDMYR, SPIGBI, SPICBI, MGB, MCB

$\mathrm{R}_{\text {Index }}=$ return on CSPI, KLCI

To check whether GOLDIDR, SPIGBI, and SPICBI could act as a robust safe haven in Indonesia, the data's analysis were also done by employing a Quantile Regression (QREG).

The QREG equation used is as follows:

$\mathrm{R}_{\text {Instrument, } \mathrm{t}}=\alpha+\beta_{1} \mathrm{R}_{\operatorname{CSPI}(\mathrm{Q} 50 \%, 40 \%, 30 \%, 20 \%, 10 \%)}+$

with,

$\varepsilon_{\mathrm{t}} \quad=$ residual term

$\mathrm{R}_{\text {Instrument,t }}=$ return on GOLDIDR, SPIGBI, SPICBI

$\mathrm{R}_{\mathrm{CSPI}(\mathrm{Q} 50 \%, 40 \% 30 \%, 20 \% 10 \%)}=$ return on CSPI for Q50 percent, 40 percent, 30 percent, 20 percent and 10 percent.

To check whether GOLDMYR, MGB, and MCB could act as robust safe havens in Malaysia, the data's analysis were also done by employing a Quantile Regression (QREG).

The QREG equation used is as follows:

$\mathrm{R}_{\text {Instrument,t }}=\alpha+\beta_{1} \mathrm{R}_{\mathrm{KLCI}(\mathrm{Q} 50 \%, 40 \%, 30 \%, 20 \%, 10 \%)}+\varepsilon_{\mathrm{t}}$

with,

$\varepsilon_{\mathrm{t}} \quad=$ residual term
$\mathrm{R}_{\text {Instrument, } t}=\underset{\text { MCB }}{\text { return on GOLDMYR, MGB, }}$

$\mathrm{R}_{\mathrm{KLCI}(\mathrm{Q} 50 \%, 40 \% 30 \%, 20 \% 10 \%)}=$ return on $\mathrm{KLCI}$ for Q50 percent, 40 percent, 30 percent, 20 percent and 10 percent.

This Quantile Regression (QREG) technique is commonly applied by studies into the potency of gold as a hedging instrument and a safe haven, such as those conducted by Baur and Lucey (2010); Ciner et al. (2012); Ibrahim and Baharom (2012); Ghazali et al. (2013); Ghazali et al. (2015). The QREG technique can also provide the instrument sensitivity and robustness toward the worsening condition of the financial market.

\section{Diagnostic, Robustness and Sensitivity Test}

Before analyzing the data, several diagnostic tests were conducted to detect any potential violations against the OLS's and QREG's assumptions. Those tests were model stability tests using the Augmented Dickey-Fuller (ADF) test (Robiyanto and Puryandani 2015) and the Cumulative Sum of Squares (CUSUM) test. This method had also been used by Parkyn and Vehbi (2013). While a heteroscedasticity diagnostic (only for OLS) was conducted by using the Glejser test and an autocorrelation diagnostic by using $Q$ statistics in a correlogram of residuals. The data normality test was conducted by using the Kolmogorov Smirnov test.

This study used the Theil coefficient to measure the robustness of the model. As a scale invariant, the Theil coefficient lies between zero and one. If the Theil coefficient equals zero, then the model has a perfect fit (Woschnagg and Cipan 2004). Meanwhile, 
a sensitivity test was conducted by adding some data to check whether the results were sensitive enough to the sample size chosen for the model's estimation (Parkyn and Vehbi 2013). To check the model's sensitivity, some periods were added to the analysis; these periods were October 2016 to September 2017.

\section{Results}

The results of the analysis done using the Quantile Regression (QREG) are shown in Table 1 and indicate that gold (in the local currency) tends to not be a safe haven for stocks on the Indonesian Stock Exchange. It can be seen from the result of QREG's analy- sis that quantiles 50 percent to 10 percent, except for 30 percent, all have a significant positive sign. In the quantile of 50 percent, CSPI has a positive influence on GOLDIDR with a 10 percent significance level. In the quantile of 40 percent, CSPI has a positive influence on GOLDIDR with a 5 percent significance level; while in the quantile of 30 percent, CSPI has a coefficient of effect with an insignificant positive mark. Further, in the quantiles of 20 percent and 10 percent, CSPI has a positive effect on GOLDIDR with significance levels of 1 percent. It shows that more extreme turmoil in the capital market causes a large negative return due to the selling actions of investors, increasing the effect of the transmission from the capital market

Table 1. Results of Quantile Regression Analysis for Indonesian Stock Market

\begin{tabular}{lcccccc}
\hline & & \multicolumn{5}{c}{ Quantile } \\
\cline { 3 - 7 } & OLS & 0.5 & 0.4 & 0.3 & 0.2 & 0.1 \\
\hline GOLDIDR & & & & & \\
C & 0.091294 & -0.001441 & $-0.015306 *$ & $0.026769 * * *$ & $-0.050878 * * * *$ & $-0.065199 * * *$ \\
& $(0.862608)$ & $(-0.171683)$ & $(-1.773778)$ & $(-3.120291)$ & $(-5.796004)$ & $(-8.022388)$ \\
CSPI & 0.459889 & $0.502531 *$ & $0.574184 * *$ & 0.404172 & $0.693300 * * * *$ & $0.721502 * * *$ \\
SPIGBI & $(0.139665)$ & $(1.783144)$ & $(2.094474)$ & $(1.353598)$ & $(3.357103)$ & $(4.311157)$ \\
C & & & & & & \\
& $0.007366 * * *$ & $0.007025 * * *$ & $0.005437 * * *$ & $0.003671 * * *$ & 0.000718 & $-0.006230 *$ \\
CSPI & $(5.105329)$ & $(5.487495)$ & $(4.222804)$ & $(2.999475)$ & $(0.580991)$ & $(-1.695479)$ \\
& $0.241701 * * * *$ & $0.276389 * * *$ & $0.270380 * * *$ & $0.294424 * * *$ & $0.329156 * * * *$ & $0.265689 * * *$ \\
SPICBI & $(5.384723)$ & $(4.228367)$ & $(3.875160)$ & $(4.897639)$ & $(8.219179)$ & $(4.057114)$ \\
C & & & & & & \\
& 0.092925 & 0.010928 & -0.008699 & $-0.018153 * *$ & $-0.037737 * * * *$ & $-0.063796 * * *$ \\
& $(0.951556)$ & $(1.394010)$ & $(-1.090215)$ & $(-2.381954)$ & $(-4.613994)$ & $(-5.704789)$ \\
CSPI & -0.129883 & -0.356419 & -0.213407 & -0.144523 & -0.142041 & 0.141862 \\
& $(-0.042748)$ & $(-1.382686)$ & $(-0.996820)$ & $(-0.821449)$ & $(-0.881032)$ & 0.680281 \\
\hline
\end{tabular}

Source: Various sources, processed.

Note: Numbers in parentheses are $t$-statistics

$*$ significant at significance level of $10 \%$; $*$ significant at significance level of $5 \%$; $* * *$ significant at significance level of $1 \%$ 
to gold instruments. Gold investors are also performing selling actions, because of the psychological effects (fear) of the investors in Indonesia's capital market.

A different result is found in the quantile of 30 percent, where CSPI has an insignificant effect. It indicates that at a certain point, investors experience apprehension (nervousness) that makes it difficult to determine whether to perform a buying or selling action. In general, these QREG results indicate that gold cannot act as a safe haven for the Indonesian capital market. Therefore, based on that result, H1a is rejected. By using the data from all the periods, it is found that CSPI does not have a significant influence on gold.
However, the sign for CSPI's effect is positive. It shows that gold cannot serve as a hedge for Indonesia's capital market but may function as a diversifier instrument.

The same results are also found for the Indonesian government's bond, all the quantile regressions' results show that CSPI's regression coefficients have a positive sign and a significant effect on SPIGBI. These findings show that government bonds cannot act as safe havens for the Indonesian capital market. Based on that, $\mathrm{H} 2 \mathrm{a}$ is rejected. On the contrary, almost all quantile regression coefficients, except quantile 10 percent, show that the CSPI's regression coefficients have a negative sign but no significant effect

\section{Table 2. Results of Quantile Regression Analysis for Malaysian Stock Market}

\begin{tabular}{|c|c|c|c|c|c|c|}
\hline & \multirow[b]{2}{*}{ OLS } & \multicolumn{5}{|c|}{ Quantile } \\
\hline & & 0.5 & 0.4 & 0.3 & 0.2 & 0.1 \\
\hline \multicolumn{7}{|c|}{ GOLDMYR } \\
\hline $\mathrm{C}$ & $\begin{array}{c}0.008813 \\
(1.572546)\end{array}$ & $\begin{array}{c}0.010142 \\
(1.434615)\end{array}$ & $\begin{array}{l}-0.001882 \\
(-0.267754)\end{array}$ & $\begin{array}{l}-0.014475^{*} \\
(-1.908745)\end{array}$ & $\begin{array}{c}-0.036318 * * * * \\
(-3.869150)\end{array}$ & $\begin{array}{c}-0.055597 * * * \% \\
(-5.700055)\end{array}$ \\
\hline KLCI & $\begin{array}{l}-0.236076 \\
(-1.491947)\end{array}$ & $\begin{array}{l}-0.416204^{*} \\
(-1.794120)\end{array}$ & $\begin{array}{l}-0.450135^{*} \\
(-1.821934)\end{array}$ & $\begin{array}{l}-0.307477 \\
(-1.149872)\end{array}$ & $\begin{array}{c}-0.115045 \\
(-0.412169)\end{array}$ & $\begin{array}{c}-0.080885 \\
(-0.307525)\end{array}$ \\
\hline \multicolumn{7}{|l|}{ MGB } \\
\hline $\mathrm{C}$ & $\begin{array}{c}0.003308 * \% * \% \\
(5.366784)\end{array}$ & $\begin{array}{c}0.004068^{* * * \%} \\
(7.586106)\end{array}$ & $\begin{array}{c}0.002890 * \% * \% \\
(5.262066)\end{array}$ & $\begin{array}{c}0.001973 * \% * \% \\
(3.488868)\end{array}$ & $\begin{array}{c}6.88 \mathrm{E}-06 \\
(0.008259)\end{array}$ & $\begin{array}{l}-0.003889^{*} \\
(-1.695000)\end{array}$ \\
\hline KLCI & $\begin{array}{c}0.014750 \\
(0.847477)\end{array}$ & $\begin{array}{l}-0.000740 \\
(-0.042421)\end{array}$ & $\begin{array}{c}0.015200 \\
(0.728418)\end{array}$ & $\begin{array}{c}-0.000638 \\
(-0.034667)\end{array}$ & $\begin{array}{c}0.013879 \\
(0.665431)\end{array}$ & $\begin{array}{c}0.042639 \\
(1.302166)\end{array}$ \\
\hline \multicolumn{7}{|l|}{ MCB } \\
\hline $\mathrm{C}$ & $\begin{array}{c}0.004488 \% \% \% \\
(7.231170)\end{array}$ & $\begin{array}{c}0.004126 \% * \% \\
(6.178943)\end{array}$ & $\begin{array}{c}0.003020 * \% * \% \\
(4.729560)\end{array}$ & $\begin{array}{l}0.001628 \% \\
(2.329572)\end{array}$ & $\begin{array}{c}0.000889 \\
(1.370983)\end{array}$ & $\begin{array}{c}-0.001828 \% * \\
(2.159033)\end{array}$ \\
\hline KLCI & $\begin{array}{c}0.025876 \\
(1.476786)\end{array}$ & $\begin{array}{c}0.013810 \\
(0.600644)\end{array}$ & $\begin{array}{c}0.032629 \\
(1.315124)\end{array}$ & $\begin{array}{l}0.047060 * \\
(1.859818)\end{array}$ & $\begin{array}{l}0.042109 * \\
(1.975706)\end{array}$ & $\begin{array}{c}0.061353 * \% * \% \\
(4.570112)\end{array}$ \\
\hline
\end{tabular}

Source: Various sources, processed.

Note: Numbers in parentheses are probability level

$*$ significant at significance level of $10 \%$; $* *$ significant at significance level of $5 \%$; *** significant at significance level of $1 \%$ 
on SPICBI. These findings show that corporate bonds can act as a safe haven for the Indonesian capital market. Based on that, $\mathrm{H} 3 \mathrm{a}$ is accepted. Additionally, the results show that the role of corporate bonds, as a safe haven, will fade away as the market worsens dramatically.

Inconsistent results are found for the capital market in Malaysia. In contrast to the Indonesian capital market, gold is able to become a safe haven for the Malaysian capital market (KLSE). As stock market conditions become more volatile, gold still shows its existence as a safe haven for the Malaysian capital market. This is indicated by the QREG's KLCI regression coefficient which is always signed negatively from the 50 percent quantile to the 10 percent quantile in Table 2. Based on that, $H 1 b$ is accepted. The OLS results also show that gold can be a hedging instrument for the KLCI because the KLCI's regression coefficient is negative. This finding is supported by the research of Ibrahim and Baharom (2012).

Based on the OLS result, it can be concluded that the Malaysian Govern-ment's Bond (MGB) cannot act as a hedging instrument for the KLSE, but for the MGB it could act as a diversifier. The QREG's result also shows that the MGB could not act as a robust safe haven for the KLSE. Only QREG with the quantile of 50 percent and the quantile of 30 percent have an insignificant negative sign; the other quantiles have a positive and insignificant sign. Based on that, $H 2 b$ is rejected.

Some similar results are also found in the Malaysian Corporate Bond (MCB) model. Based on the OLS result, which produced an insignificant positive coefficient, the $\mathrm{MCB}$ could act as a diversifier, but not a hedging instrument, for the KLSE. Moreover, based on the QREG's result, the MCB cannot act as safe haven for the KLSE because all the QREG's results in every quartile show a positive regression coefficient, even for the quantiles of 30 percent, 20 percent and 10 percent, the regression coefficients in those models become positive and significant (the quantiles of 30 percent and 20 percent are significant at the 10 percent significance level, while the quantile of 10 percent is significant at the 1 percent significance level). Based on that, $H 3 b$ is rejected. The findings also show that if there is extreme turmoil on the KLSE, there is a higher positive correlation between the MCB and KLSE.

\section{Diagnostic Test Results}

Both the ADF test (as shown in Table 3) and the CUSUM test results for OLS (as shown in Figure 1) are not suggestive of any instability (in both the parameters and variance) in the models.

The results of the heteroscedasticity diagnostic (only for OLS) by using the Glejser test (as shown in Table 4 and Table 5) and

Table 3. Augmented Dickey-Fuller (ADF) Test Result

\begin{tabular}{lcc}
\hline Variable & $\begin{array}{c}\text { Augmented } \\
\text { Dickey-Fuller } \\
\text { (ADF) Statistic }\end{array}$ & Probability \\
\hline GOLDIDR & -10.87009 & 0.00000 \\
SPIGBI & -5.921121 & 0.00000 \\
SPICBI & -10.92247 & 0.00000 \\
GOLDMYR & -12.60202 & 0.00000 \\
MGB & -9.038593 & 0.00000 \\
MCB & -16.49468 & 0.00000 \\
\hline
\end{tabular}

Source: Various sources, processed 
Figure 1. CUSUM Test Results For OLS

GOLD
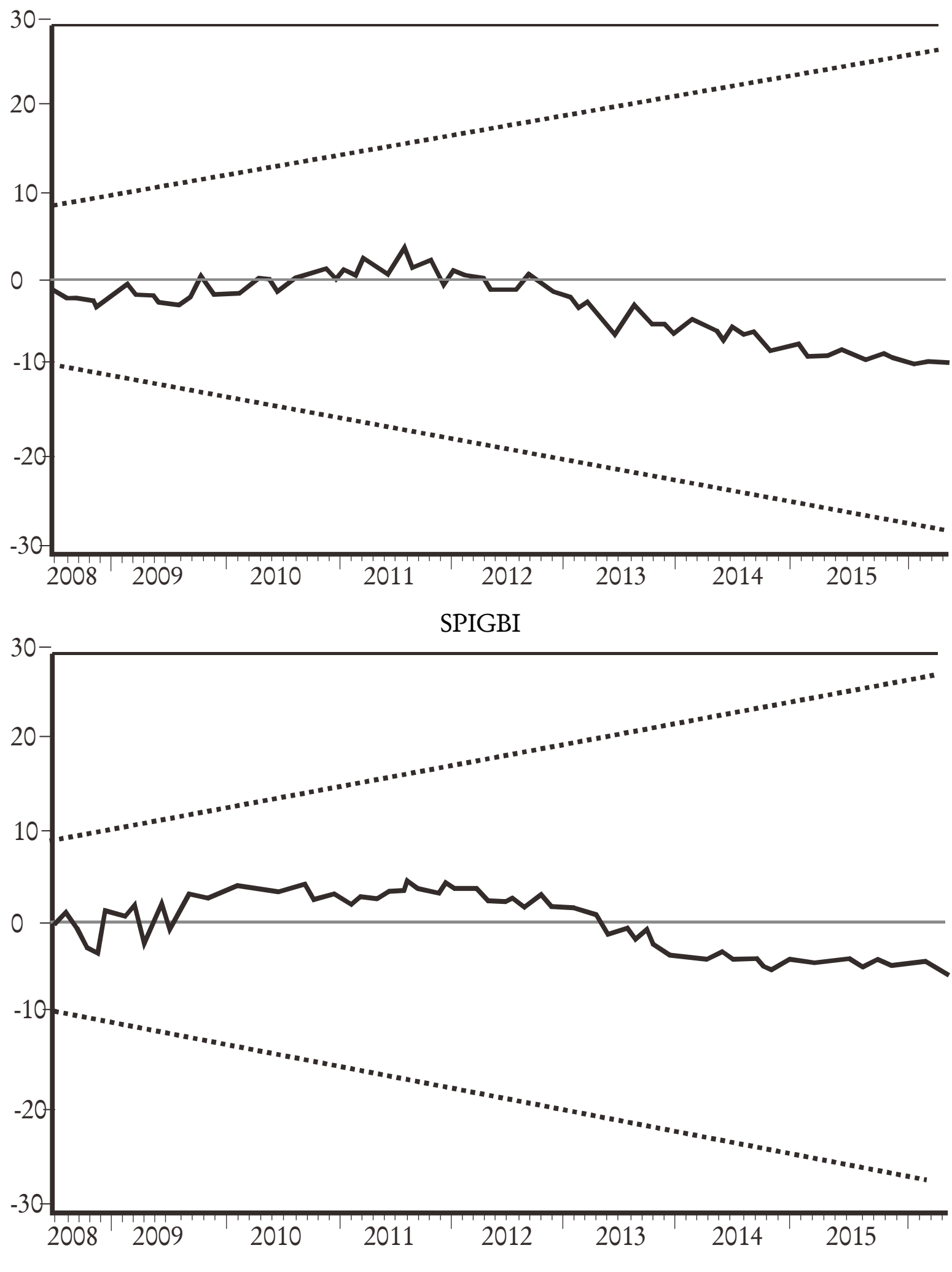
Gadjah MadaInternational Journal of Business-Sept-Dec., Vol. 20,No.3,2018

Figure 1. Continued
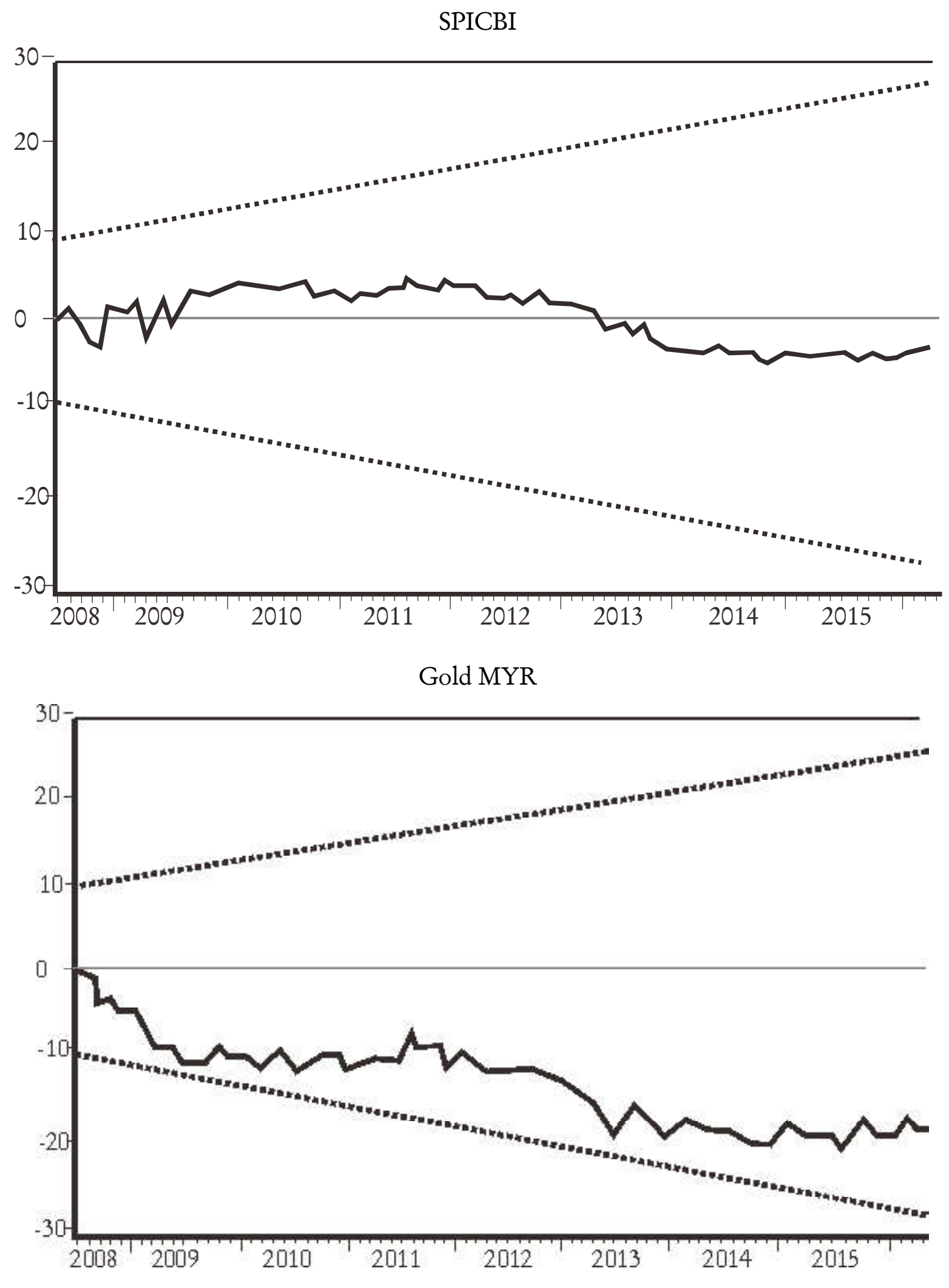
Figure 1. Continued

the autocorrelation diagnostic by using $\mathrm{Q}$ statistics in the correlogram of residuals (as shown in Table 6) do not indicate any significant autocorrelation for a 1 percent level of significance or hetero-scedasticity in the models.

Table 4. Heteroscedasticity Test Result by Using Glejser Test (For OLS Only) For Indonesian Stock Market

\begin{tabular}{ccc}
\hline $\begin{array}{c}\text { Dependent } \\
\text { Variable }\end{array}$ & $\begin{array}{c}\text { Independent } \\
\text { Variable }\end{array}$ & t statistic \\
\hline GOLDIDR & CSPI & $\begin{array}{c}0.191451 \\
(0.9553)\end{array}$ \\
SPIGBI & CSPI & $\begin{array}{l}0.709653 \\
(0.4796)\end{array}$ \\
& & 0.127250 \\
SPICBI & CSPI & $(0.8990)$ \\
\hline
\end{tabular}

Source: Various sources, processed.

Note: Numbers in parentheses are probability level
The data normality test was conducted by using the Kolmogorov Smirnov (as shown in Table 7) and all the variables were normally distributed.

Table 5. Heteroscedasticity Test Result by Using Glejser Test (For OLS Only) For Malaysian Stock Market

\begin{tabular}{ccc}
\hline $\begin{array}{c}\text { Dependent } \\
\text { Variable }\end{array}$ & $\begin{array}{c}\text { Independent } \\
\text { Variable }\end{array}$ & t statistic \\
\hline \multirow{2}{*}{ GOLDMYR } & KLCI & $\begin{array}{c}0.995975 \\
(0.3217)\end{array}$ \\
& KLCI & -1.795725 \\
MGB & & $(0.0756)$ \\
& KLCI & -0.873042 \\
MCB & & $(0.3847)$ \\
\hline
\end{tabular}

Source: Various sources, processed.

Note: Numbers in parentheses are probability level

Table 6. Autocorrelation Test Result by Correlogram (36 Lags)

\begin{tabular}{ccccccc}
\hline & \multicolumn{6}{c}{ Quantile } \\
\cline { 2 - 7 } & OLS & 0.5 & 0.4 & 0.3 & 0.2 & 0.1 \\
\hline GOLDIDR & None & None & None & None & None & None \\
SPIGBI & None & None & None & None & None & None \\
SPICBI & None & None & None & None & None & None \\
GOLDMYR & None & None & None & None & None & None \\
MGB & None & None & None & None & None & None \\
MCB & None & None & None & None & None & None \\
\hline
\end{tabular}

Source: Various sources, processed.

Information: None lag has a significant Q Statistics at significance level of 1 percent 
Table 7. Data Normality Test Result

\begin{tabular}{cccc}
\hline Variable & $\begin{array}{c}\text { Kolmogorov } \\
\text { Smirnov Z }\end{array}$ & Probability & Conclusion \\
\hline GOLDIDR & 0.440 & 0.990 & Normally Distributed \\
SPIGBI & 1.229 & 0.097 & Normally Distributed \\
SPICBI & 0.612 & 0.848 & Normally Distributed \\
CSPI & 0.961 & 0.314 & Normally Distributed \\
GOLDMYR & 0.495 & 0.967 & Normally Distributed \\
MGB & 0.585 & 0.884 & Normally Distributed \\
MCB & 1.144 & 0.146 & Normally Distributed \\
KLCI & 1.078 & 0.195 & Normally Distributed \\
\hline
\end{tabular}

Source: Various sources, processed.

\section{Robustness Test Results}

As mentioned previously, this study used the Theil coefficient to measure the robustness of the model. The Theil coefficients for each model are presented in Table 8.

According to Woschnagg and Cipan (2004), the smaller the Theil coefficient is, the better the model is. Based on Table 6., the SPIGBI models are better than any model resulted in this study, both for the Indonesian capital market and the Malaysian capital market. The SPIGBI models' Theil coefficients are spanning from 0.450681 to 0.701115 . The SPIGBI OLS's Theil coefficient is the smallest and increases gradually, regarding the smaller quantile used. This means that a smaller quantile will lead to less fit models, because the SPIGBI tends to become a hedge for the IDX over time. The SPICBI OLS's Theil coefficient is the smallest among the SPICBI's models. However, by looking at the SPICBI models in any quartiles, any of them that show a smaller quartile will produce a smaller Theil coefficient, so it can be concluded that more severe financial market conditions will lead to a better fit. This may happen because almost all the CSPI's regression coefficients in the SPICBI models are negative. For the Malaysian capital market, the MCB's OLS model produces the lowest Theil coefficient, but the finding shows that MCB can only act as a diversifier for the Malaysian capital market because the regression coefficient is positive but insignificant.

For the GOLDIDR models, the OLS model has the smallest Theil coefficient. This finding doesn't mean that gold is a robust safe haven because the CSPI's regression coefficients in the GOLDIDR models are positive. This indicates that the more severe the market's condition is, the higher the positive correlation between gold and the CSPI is. While for GOLDMYR, the QREG with the 50 percent quartile model has the smallest Theil coefficient. Since the KLCI's regression coefficient in this model has a consistent negative sign, this shows that gold can act as a safe haven for the Malaysian capital market. 
Gadjah MadaInternational Journal of Business-Sept-Dec., Vol. 20,No.3,2018

Table 8. Theil Coefficient for Each Model

\begin{tabular}{ccccccc}
\hline & & \multicolumn{5}{c}{ Quantile } \\
\cline { 3 - 7 } & OLS & 0.5 & 0.4 & 0.3 & 0.2 & 0.1 \\
\hline GOLDIDR & 0.908610 & 0.984213 & 0.981094 & 0.976924 & 0.958136 & 0.948175 \\
SPIGBI & 0.450681 & 0.442368 & 0.464738 & 0.482595 & 0.520533 & 0.701115 \\
SPICBI & 0.905891 & 0.985055 & 0.987932 & 0.981247 & 0.964353 & 0.945295 \\
GOLDMYR & 0.812078 & 0.756023 & 0.783138 & 0.797720 & 0.762850 & 0.753315 \\
MGB & 0.586745 & 0.557070 & 0.612250 & 0.700396 & 0.928037 & 0.854542 \\
MCB & 0.495296 & 0.516898 & 0.570835 & 0.668281 & 0.747141 & 0.846166 \\
\hline
\end{tabular}

Source: Various sources, processed.

Figure 2. GOLDIDR Model's Sensitivity Analysis



Source: Various sources, processed. 
Figure 3. SPIGBI Model's Sensitivity Analysis

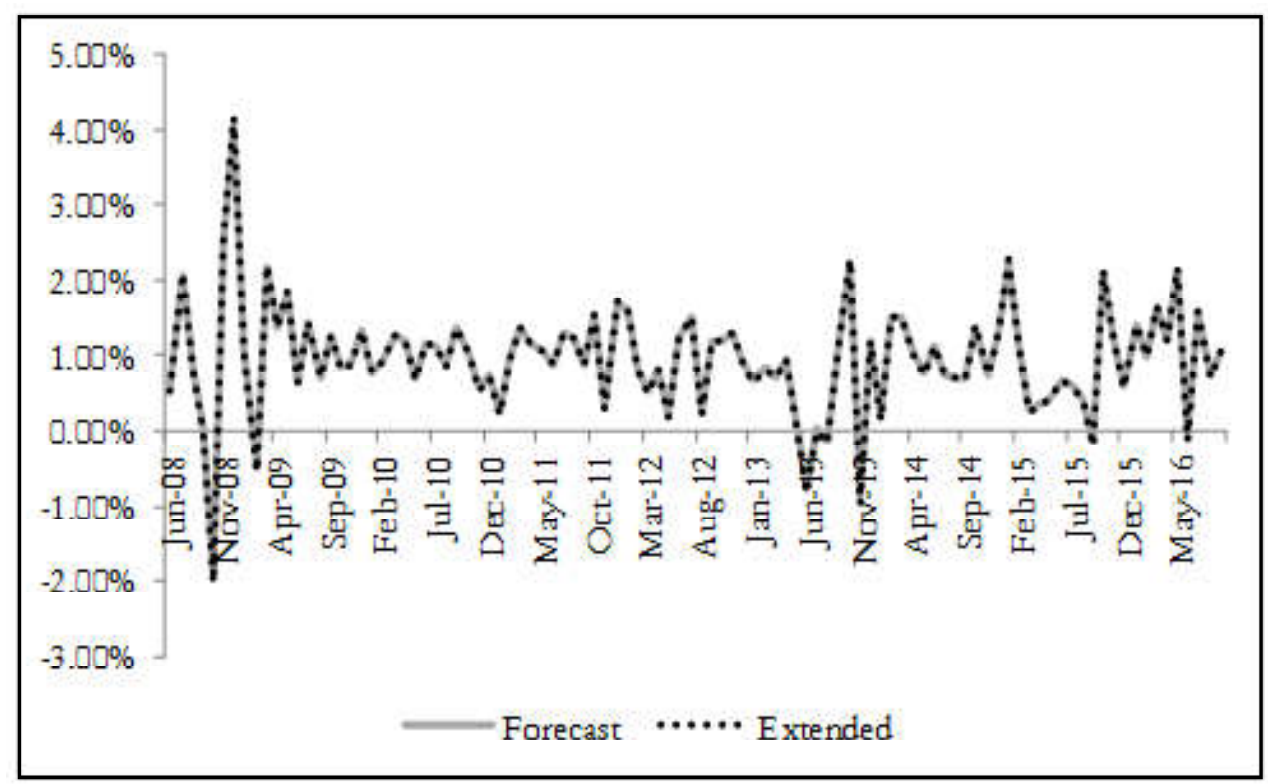

Source: Various sources, processed

Figure 4. SPICBI Model's Sensitivity Analysis

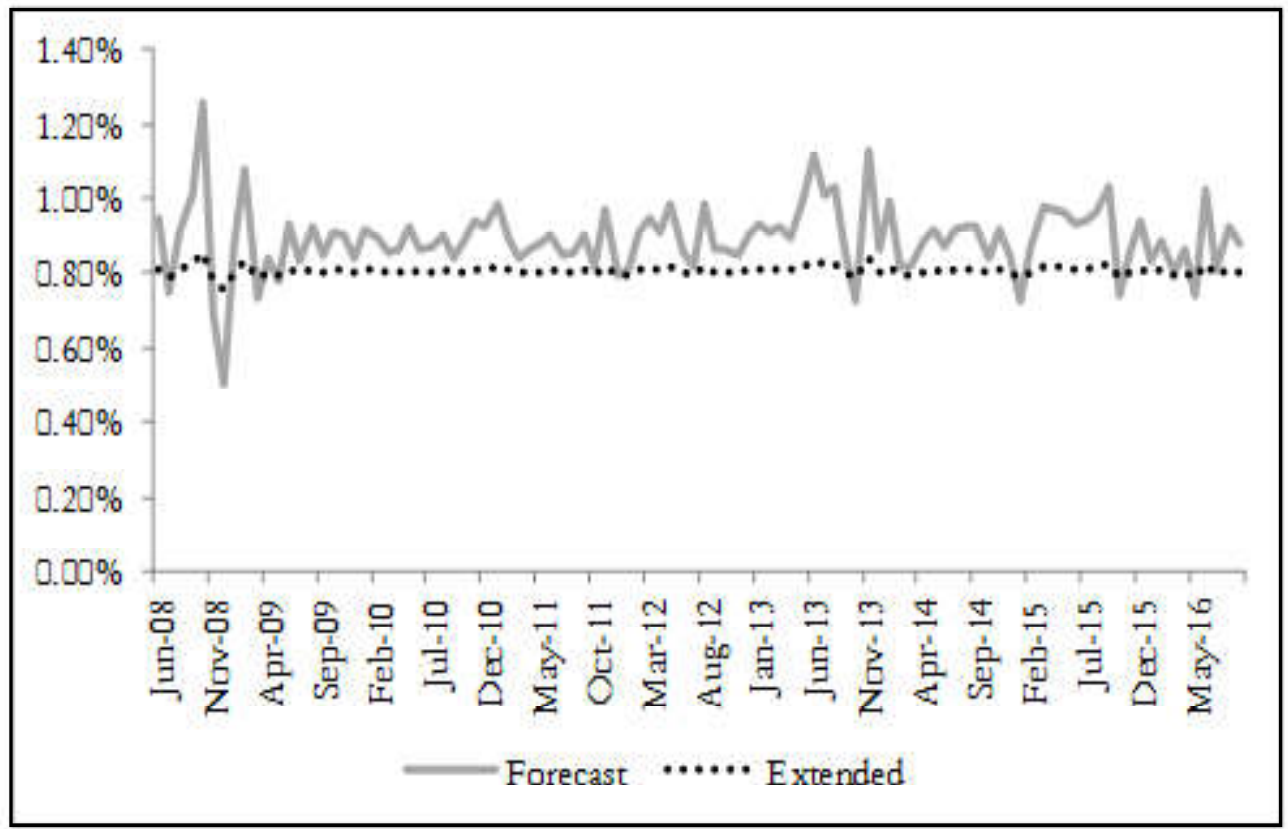

Source: Various sources, processed. 
Gadjah MadaInternational Journal of Business-Sept-Dec., Vol. 20,No.3,2018

Figure 5. GOLDMYR Model's Sensitivity Analysis

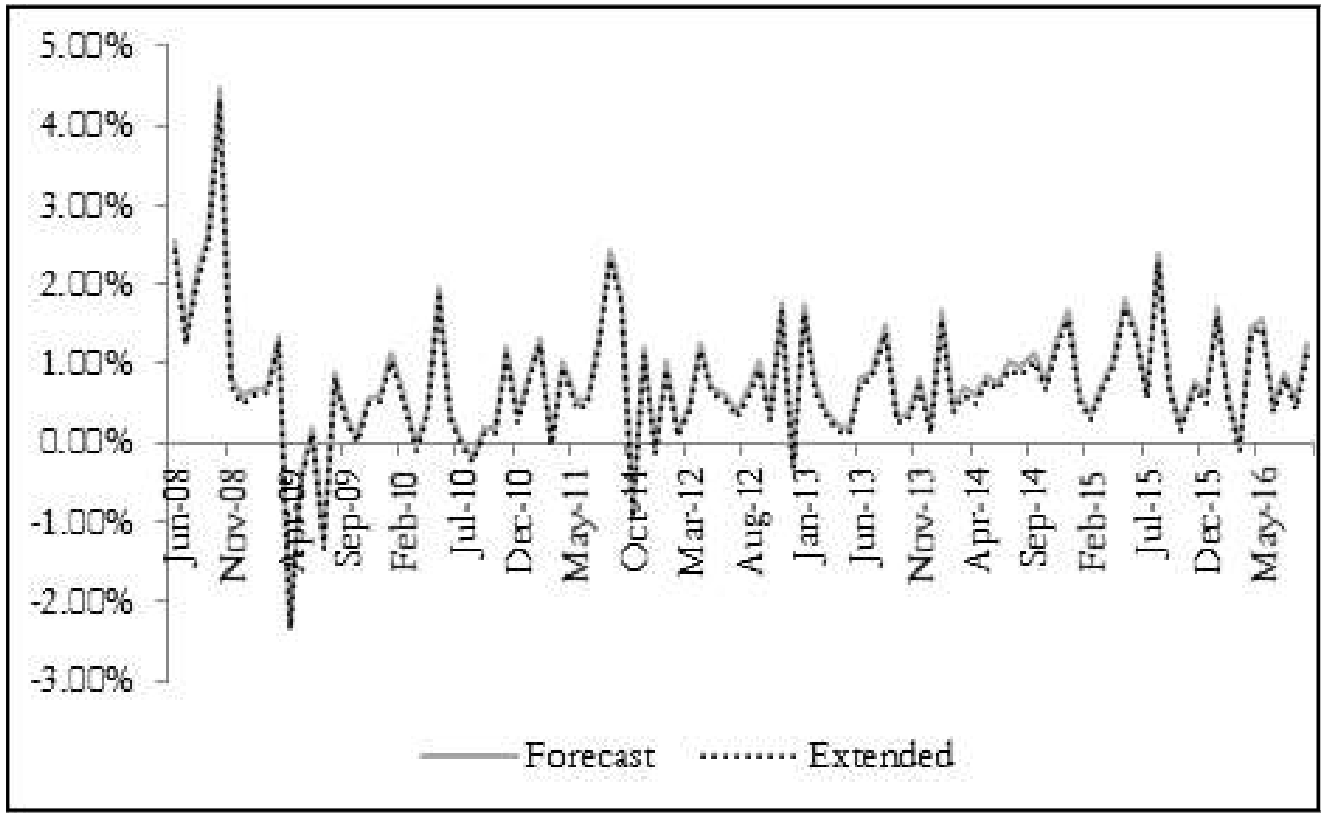

Source: Various sources, processed.

Figure 6. MGB Model's Sensitivity Analysis

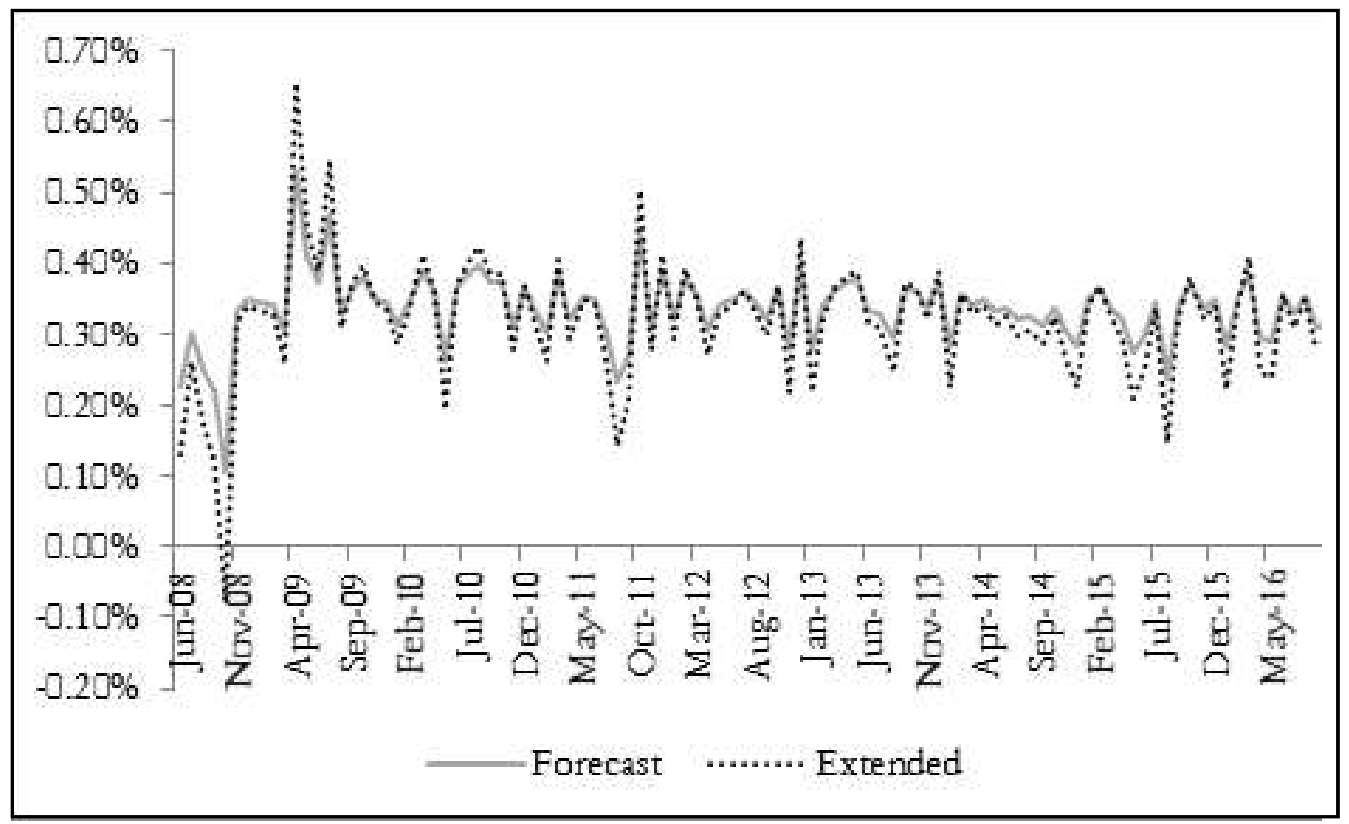

Source: Various sources, processed. 
Figure 7. MCB Model's Sensitivity Analysis

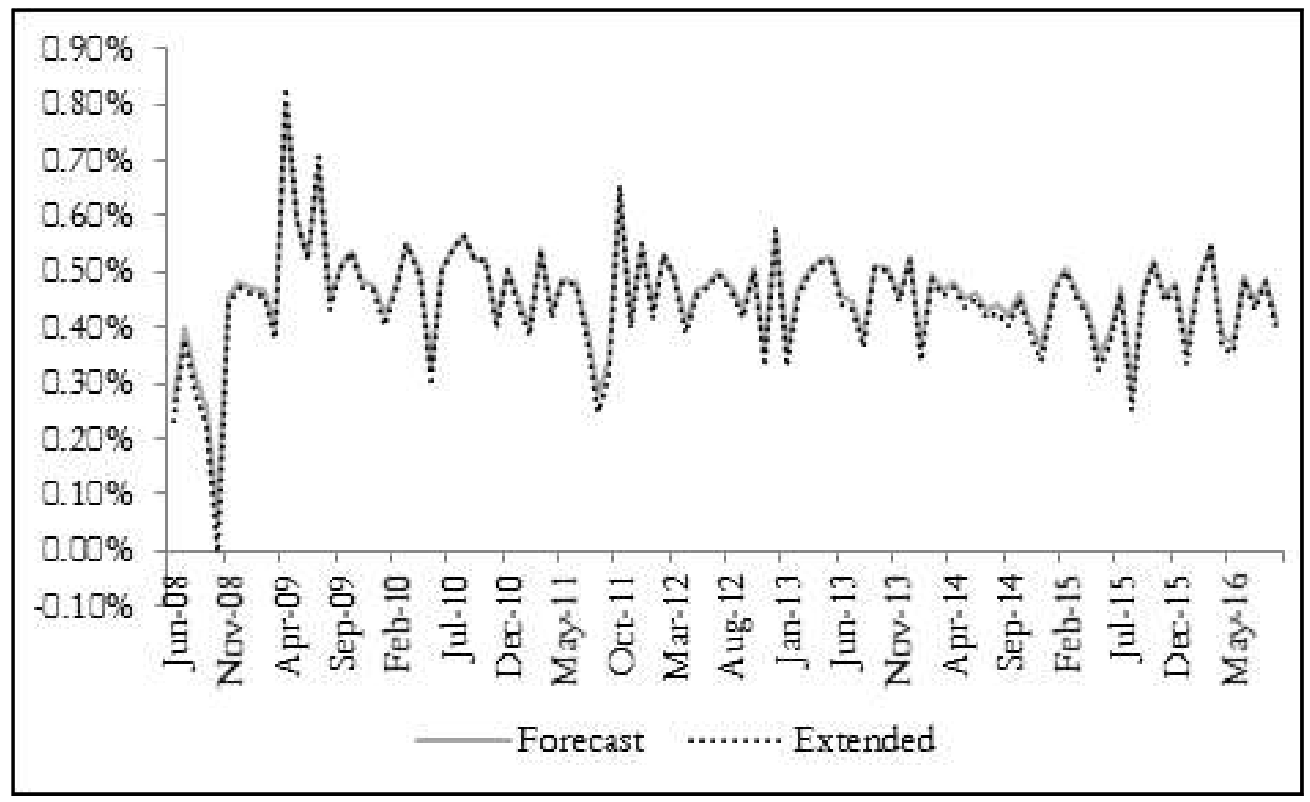

Source: Various sources, processed

\section{Sensitivity Test Results}

To examine whether the model's results are not sensitive to the sample size chosen, the researcher added some periods that could potentially lead to parameter instabilities. The researcher re-estimated the model for the period from June 2008 to September 2017. The results tend to have a low sensitivity and are fairly robust. The results for the Indonesian stock market can be seen in Figure 2, Figure 3, and Figure 4; while the results for the Malaysian stock market can be seen in Figure 5, Figure 6, and Figure 7.

\section{Discussion}

The inability of gold to become a safe haven for the Indonesian capital market is consistent with several previous studies, such as the research undertaken by Ghazali et al. (2013); Ghazali et al. (2015); Ibrahim and Baharom (2012). Ghazali et al. (2013) even suggested that when the condition of the capital market gets worse, stocks on the capital market will tend to have the same movement to gold and the same is also found in this study. However, this study finds that gold can act as a robust safe haven for the Malaysian capital market. This finding is the opposite of almost all the studies done on the Malaysian capital market, i.e. Ibrahim and Baharom (2012); Ghazali et al. (2013); Ghazali et al. (2015). This might have happened because this study used a longer period which consisted of various market dynamics.

This finding supports the idea that gold can serve as a diversifier instrument for the Indonesian stock market and is consistent with the findings of Ibrahim and Baharom (2012) who had previously studied the Malaysia capital market (Kuala Lumpur Stock Exchange). This study also supports the arguments of several other experts, such as 
Chua et al. (1990); Hoang et al. (2015) who all stated that gold can function as a diversifier instrument in a portfolio. Meanwhile, this study also finds that gold can act as a hedging instrument for the Malaysian capital market across time.

The results of the analysis, as listed in Table 1 and Table 2 show that the Indonesian government's bonds (represented by SPIGBI), the Malaysian government's bonds (represented by MGB) and the Malaysian corporate bonds (represented by MCB) are entirely incapable of functioning as hedges and safe havens for their respective capital markets. This is indicated by the significance of the positive effect of CSPI on CSPI for all the quantiles used and on all the data analyzed with OLS at the 1 percent significance level. For the Malaysian capital market, it is indicated by the insignificant positive effect of the KLCI in most MGB models (only in the quantile of 50 percent and 30 percent, is there an insignificant negative effect). In the Malaysian capital market, $\mathrm{MCB}$ could act as a diversifier asset across the research period, but the MCB cannot act as a safe haven for the Malaysian capital market. MCB tends to have a significant and positive relationship with the KLCI during the market's turbulence, which becomes stronger as the market's condition worsens.

This finding indicates that there is a close co-movement between stocks and government bonds in both the Indonesian and Malaysian capital markets in all conditions; and close co-movement between the Malaysian corporate bond and the KLCI. This also implies that Indonesian government bonds are also unable to become a diversifier asset for stocks on the Indonesian capital market. On the contrary, Malaysian government bonds and Malaysian corporate bonds can act as diversifier assets for stocks on the Malay- sian capital market. The inability of government bonds to serve as a hedge for the capital markets is in line with the research findings from Ciner et al. (2012) conducted in the United States.

Unlike Indonesian government bonds, Malaysian government bonds and Malaysian corporate bonds, all of which cannot serve as safe havens, Indonesian corporate bonds are surprisingly capable of performing the role of a safe haven and a hedge. It can be seen from the coefficient of the CSPI's influence with negative marks on the quartiles of 50 percent, 40 percent, 30 percent, and 20 percent. However, this coefficient of the CSPI's influence turns positive, although insignificant, on the quartile of 10 percent, indicating that the corporate bonds are not a robust safe haven for Indonesia's capital market. The OLS analysis produces the coefficient of the CSPI's influence with an insignificant negative mark, meaning that corporate bonds may serve as a hedge for stocks on Indonesia's capital market.

The findings in this study are quite surprising because government bonds, which are supposed to be able to serve as a safe haven for stocks should exist, as found in Cineret al. (2012). Government bonds' interest rates are often referred to as risk-free rate calculations, for they are considered to be a risk-free instrument (Thillainathan 1996; Heng et al. 2005; Fen et al. 2014).

This condition may occur due to the fact that Indonesian and Malaysian government bonds are in demand by foreign investors. Based on the data published by Gadjah Mada University (UGM) in 2015, it is noted that the share of foreign ownership of SUN by October 2015 was 37 percent. For Malaysian government bonds, according to BNM (2018), the share of foreign ownership in September 2016 was 33.8 percent (which 
had increased from 29.7 percent in 2014). Hence, both the Indonesian government's bonds and Malaysian government's bonds tended to be more vulnerable to turbulence in the capital markets, or to any change in interest rates, as these foreign institutional investors would tend to sell their investment instruments to secure their portfolios.

In Indonesia, corporate bonds, in most of the transactions, are dominated by local investors (institutions) such as pension funds, mutual funds, and other institutions. These local institutional investors tend to possess long-term bonds, many of whom bought the bonds at the initial public offerings and held the corporate bonds to maturity (hold to maturity) so they tend to be less liquid (for example, based on "Capital Market Statistics 2017" published by the Financial Services Authority or OJK in 2017), the frequency of SUN transactions during 2016 was 212,797 times, compared to the frequency of corporate bond transactions during 2016 which was 24,398 times; a similar result also happened to the amount of SUN transaction in 2016 which reached IDR $3,649,061$ trillion, compared to the corporate bond transactions in 2016, which amounted to IDR 224,317 trillion. Relatively similar cases also happened in the previous years.

\section{Conclusion}

The findings of this study indicate that gold cannot function as a safe haven for the Indonesian capital market but can act as a robust safe haven for the Malaysian capital market. This study also finds that gold is not able to become a hedge for the Indonesian stock market; however, it indicates that gold can serve as a diversifier (in both the Indonesian and Malaysian capital markets).
Indonesian government bonds, Malaysian government bonds, and Malaysian corporate bonds could serve as hedges and safe havens because they tended to have a comovement in all conditions. This co-movement is strengthened when market conditions worsen. In contrast, corporate bonds in Indonesia have the potential to perform a function as a hedge and safe haven for stocks on the Indonesian Stock Exchange. However, as the market's condition worsened, the ability of corporate bonds in Indonesia to act as a safe haven for the Indonesian Stock Exchange faded.

Stock investors in Indonesia may add the gold instrument into their portfolios, which also consist of stocks, as gold is proven to be a diversified instrument in portfolios of the Indonesian Stock Exchange. Investors do better to not transfer their stocks to Indonesia's government bonds when conditions decline on the Indonesian stock market, due to powerful co-movements between the stock market and the Indonesian government bonds market. Nevertheless, investors may use corporate bonds as a hedge and safe haven for stocks on the Indonesian Stock Exchange, though they should be cautious, as the role of corporate bonds as a hedge and a safe haven will fade when stock market conditions are declining rapidly. Stock investors in Malaysia should use gold (Kijang Emas) as a safe haven instrument to preserve their investments' value during market turbulence. In the long term, it is also suggested that Malaysian investors add either Malaysian government bonds or Malaysian corporate bonds into their portfolios, because both instruments are proven diversifier instruments for the KLCI.

This study used monthly data so that the observation period generated was rela- 
tively limited and it was not possible to conduct a QREG study on 1 percent and 2.5 percent quartiles. The use of daily data is highly recommended to acquire a larger number of observations, so future studies can be performed with smaller quartiles (e.g., 1 percent and 2.5 percent). Although this research employs S\&P Indonesian Corporate Bond Index (SPICBI) and S\&P Indonesian Government Bond Index (SPIGBI) data, which are denominated in the local currency in Indonesia (rupiah), and also S\&P Malaysian Corporate Bond Index (MCB) and S\&P Malaysian Govern- ment Bond Index (MGB) data which are denominated in the local currency in Malaysia (ringgit), the use of bond-related indexes released some time ago by local institutions, such as the Indonesian Bond Pricing Agency (IBPA) for Indonesian bonds or Bank Negara Malaysia for Malaysian (government) bonds, may be considered. The existence of bond futures contracts, issued in 2017, can be studied further to obtain empirical evidence on the potency of bond futures contracts as a hedge, a safe haven, and a diversified instrument.

\section{References}

Agyei-Ampomah, S., D. Gounopoulos, and K. Mzaouz. 2013. Does gold offer a better protection against sovereign debt crisis than other metals. In EFMA.

Arouri, M. E. H., A. Lahiani, and D. K. Nguyen. 2014. World gold prices and stock returns in China: Insights for hedging and diversification strategies. Working Paper.

Baur, D. G. 2013. Gold-fundamental drivers and asset allocation. In SSRN: Electronic copy available at: http://ssrn.com/abstract $=2240831$.

Baur, D. G., and B. M. Lucey. 2010. Is gold a hedge or a safe haven? An analysis of stocks, bonds and gold. The Financial Reviere 45:217-229. doi: 10.1111/j.1540-6288.2010.00244.x.

Baur, D. G., and T. K. McDermott. 2009. Is gold a safe haven?: International evidence. Institute for International Integration Studies (IIIS) Discussion Paper (310).

Baur, D. G., and T. K. J. McDermott. 2012. Safe Haven Assets and Investor Behaviour Under Uncertainty. Sydney: UTS, School of Business, Finance Discipline Group.

Beber, A., M. W. Brandt, and K. A. Kavajecz. 2006. Flight-to-quality or flight-to-liquidity? Evidence from the Euro-Area bond market. In NBER Working Paper Series: Electronic copy available at: http://www.nber.org/papers/w12376. http://www.nber.org/papers/w12376.

Bianconi, M., J. A. Yoshino, and M. O. Machado de Sousa. 2013. BRIC and the U.S. financial crisis: An empirical investigation of stock and bond markets. Emerging Markets Review no. 14:76-109. doi: https://doi.org/10.1016/j.ememar.2012.11.002.

BNM. 2018. Malaysian Government Securities (MGS) - Conventional. Bank Negara Malaysia 2018 [cited May 15 2018]. Available from http://www.bnm.gov.my.

Capie, F., T. C. Mills, and G. Wood. 2005. Gold as a hedge against the dollar. Journal of International Financial Markets Institution and Money 15: 343-352. doi: 10.1016/j.intfin.2004.07.002.

Cappiello, L., R. F. Engle, and K. Sheppard. 2006. Asymmetric dynamics in the correlations of global equity and bond returns. Journal of Financial Econometrics 4 (4): 537-572. doi: https:/ /doi.org/10.1093/jjfinec/nblo05. 
Chiang, S-M, C-T. Lin, and C-M. Huang. 2013. The relationships among stocks, bonds and gold: Safe haven, hedge or neither? In International Conference on Technology Innovation and Industrial Management. Phuket, Thailand.

Christiansen, C., and A. Ranaldo. 2007. Realized bond-stock correlation: Macroeconomic announcement effect. Journal of Futures Markets 27: 439-469. doi: 10.1002/fut.20258.

Chua, J. H., G. Sick, and R. S. Woodward. 1990. Diversifying with gold stocks. Financial Analysts Journal 46 (4): 76-79. doi: https://doi.org/10.2469/faj.v46.n4.76.

Ciner, C., C. Gurdgiev, and B. M. Lucey. 2012. Hedges and safe havens - An examination of stocks, bonds, oil, gold and the dollar. In Working Paper.

Coudert, V., and H. Raymond-Feingold. 2011. Gold and financial assets: Are there any safe havens in bear markets? Economics Bulletin 31 (2): 1613-1622.

Dee, J., L. Li, and Z. Zheng. 2013. Is gold a hedge or a safe haven? Evidence from inflation and stock market. International Journal of Development and Sustainability 2 (1): 1-16.

Faubert, V.. 2012. Is gold still a safe haven? Tresor-Economics, Ministere de L'Economie Des Finances et de L'Industrie (April ): 101.

Fen, A. B., L. S. Yee, L. C. Ling, O. C. Cher, and S. K. Yean. 2014. The determinants of Malaysia government bond yields from year 1996:Q1 to 2013:Q4. Thesis, Faculty of Business and Finance Department of Finance, Universiti Tunku Abdul Rahman.

Figuerola-Ferretti, I., and J. Gonzalo. 2010. Price discovery and hedging properties of gold and silver markets. In Working Paper.

Flavin, T. J., C. E. Morley, and E. Panopoulou. 2014. Identifying safe haven assets for equity investors through an analysis of the stability of shock transmission. Journal of International Financial Markets,Institutions and Money 33: 137-154. doi: https://doi.org/10.1016/ j.intfin.2014.08.001.

Ghazali, M. F., H-H. Lean, and Z. Bahari. 2013. Is gold a hedge or a safe haven? An empirical evidence of gold and stocks in Malaysia. International Journal of Business and Society 14 (3): 428-443.

Ghazali, M. F., H. H. Lean, and Z. Bahari. 2015. Sharia compliant gold investment in Malaysia: Hedge or safe vaven? Pacific-Basin Finance Journal. doi: https://doi.org/10.1016/ j.pacfin.2014.12.005.

Greer, R. J. 1997. What is an asset class, anyway? Journal of Portfolio Management 23 (2): 86-91. doi: $10.3905 /$ jpm.23.2.86.

Heng, N. V. , A. M. Nassir, M. Ariff, and S. Mohamad. 2005. Predictive power of forward rates: Evidence from Malaysian government securities (MGS) market. Investment Management and Financial Innovations 2: 61-71.

Hillier, D., P. Draper, and R. Faff. 2006. Do precious metals shine? An investment perspective. Financial Analysts Journal 62 (3/4): 98-106. doi: https://doi.org/10.2469/faj.v62.n2.4085.

Hoang, T-H-V, H. Hooi Lean, and W-K. Wong. 2015. Is Gold Good for portfolio diversification? A stochastic dominance analysis of the Paris Stock Exchange." International Review of Financial Analysis. doi: https://doi.org/10.1016/j.irfa.2014.11.020.

Ibrahim, M. H. 2012. Financial risk market and gold investment in an emerging market: The case of Malaysia. International Journal of Islamic and Middle Eastern Finance and Management Research Nerws 5 (1): 25-34. doi: https://doi.org/10.1108/17538391211216802. 
Ibrahim, M. H., and A. H. Baharom. 2012. The role of gold in financial market: A malaysian perspective. Economic Computation and Economic Cybernetics Studies and Research.

Joy, M. 2011. Gold and the US dollar: Hedge or haven? Finance Research Letters 8: 120-131. doi: https://doi.org/10.1016/j.frl.2011.01.001.

Kaul, A., and S. Sapp. 2006. Y2K fears and safe haven trading of the U.S. dollar. Journal of International Money and Finance 25 (5):760-779 doi: https://doi.org/10.1016/ j.jimonfin.2006.04.003.

Krondahl, E., and O. Lindahl. 2012. Perceptual Safe Havens: A Study of Gold, Oil, Palladium, Wheat, Bonds, USD, and Stocks. Degree Project Master of Science in Business and Economics, School of Economics and Management, Department of Business Administration, Lund University.

Kumar, D. 2014. Return and volatility transmission between gold and stock sectors: Application of portfolio management and hedging effectiveness. IIMB Management Revierw 26 (1): 5-16. doi: 10.1016/j.iimb.2013.12.002.

Marzo, M., and P. Zagaglia. 2010. Gold and the U.S. dollar: Tales from the turmoil. The Rimini Centre For Economic Analysis Working Paper 10 (8).

Maslov, S., and B. M. Rochner. 2004. The conundrum of stock versus bond prices. Physica A 335 (1-2): 164-182. doi: https://doi.org/10.1016/j.physa.2003.11.031.

Nastou, B. 2013. Thinking about asset alocation in 2013. Investment Insight (February): 1-6.

OJK. 2017. Statistik Pasar Modal 2017.

Parkyn, O., and T. Vehbi. 2013. The effects of fiscal policy in New Zealand: Evidence from a VAR model with debt constraints. New Zealand Treasury Working Paper.

Putra, M. P. S., A. D. R. Atahau, and R. Robiyanto. 2018. Cross-asset class portfolio between gold and stocks in Indonesia. Economic Journal of Emerging Markets 10 (1): 69-81. doi: 10.20885/ ejem.vol10.iss1.art8.

Ratner, M., and S. Klein. 2008. The portfolio implications of gold investment. Journal of Investing 17 (1): 77-87. doi: https://doi.org/10.3905/joi.2008.701958

Roache, S. K., and M. Rossi. 2010. The effects of economic news on commodity prices. Quarterly Review of Economics and Finance 50 (3): 377-385. doi: https://doi.org/10.1016/ j.qref.2010.02.007.

Robiyanto, R. 2018a. The effect of gold price changes, USD/IDR exchange rate changes and Bank Indonesia (BI) rate on Jakarta Composite Index (JCI)'s return and Jakarta Islamic Index (JII)'s return. Jurnal Manajemen dan Kewirausabaan 20 (1): 45-52. doi: https://doi.org/ 10.9744/jmk.20.1.45-52.

Robiyanto, R. 2018b. Indonesian Stock Market's dynamic integration with Asian Stock Markets and World Stock Markets. Jurnal Pengurusan 52: 181-192. doi: 10.17576/pengurusan-201852-15.

Robiyanto, R. 2018c. Testing of the gold's role as a safe haven and hedge for sharia stocks in Indonesia. Al-Iqtishad: Jurnal Ilmu Ekonomi Syariah 10 (2): 255-266. doi: 10.15408/ aiq.v10i2.6527.

Robiyanto, R., and S. Puryandani. 2015. The Javanese lunar calendar's effect on Indonesian stock returns. Gadjah Mada International Journal of Business 17 (2): 125-137. doi: 10.22146/ gamaijb.6906. 
Robiyanto, R., S. Wahyudi, and I. R. D. Pangestuti. 2017a. Testing commodities as safe haven and hedging instrument on ASEAN's five stock markets. Jurnal Ekonomi Kuantitatif Terapan 10 (2): 231-238. doi: 10.24843/JEKT.2017.v10.i02.p11

Robiyanto, R., S. Wahyudi, and I. R. D. Pangestuti. 2017b. The volatility-variability hypotheses testing and hedging effectiveness of precious metals for the Indonesian and Malaysian capital markets. Gadjah Mada International Journal of Business 19 (2): 167-192. doi: 10.22146/ gamaijb.26260.

Spall, J. 2011. How to Profit in Gold: Professional Tips and Strategies for Today's Ultimate Safe Haven Investment. New York: McGraw-Hill Companies.

Sujit, K. S., and B. R. Kumar. 2011. Study on dynamic relationship among gold price, oil price, exchange rate and stock market returns. International Journal of Applied Business and Economic Research (2): 145-165.

Sumner, S. W., R. Johnson, and L. Soenen. 2010. Spillover effects among gold, stocks, and bonds. Journal of CENTRUM Cathedra 3 (2): 109-120.

Thillainathan, R. 1996. Malaysia's bond market: The further reforms required to escape underdevelopment. ASEAN Economic Bulletin 13 (1): 95-113.

Tkacz, G. 2007. Gold prices and inflation. Bank of Canada Working Paper: 35.

Tomak, S. 2013. Is gold safe-haven? An analysis of the relationships between stock, bond, foreign exchange, and gold returns. Cag University Journal of Social Sciences 10 (1): 21-36.

Tully, E., and B. M. Lucey. 2007. A power GARCH examination of the gold market. Research in International Business and Finance 21: 316-325. doi: https://doi.org/10.1016/ j.ribaf.2006.07.001.

Universitas Gadjah Mada. 2015. Financial market update: Tim riset FMU BNI 46 FEB. 2015. Financial Outlook 2016.

Wang, L. 2012. Investment in gold: An empirical study of the gold return from 90 s to 21 st. Working Paper. Copenhagen Business School.

Worthington, A. C., and M. Pahlavani. 2007. Gold investment as an inflationary hedge: Cointegration evidence with allowance for endogenous structural breaks. Applied Financial Economics Letters 3 (4): 259-262. doi: http://dx.doi.org/10.1080/17446540601118301.

Woschnagg, E., and J. Cipan. 2004. Evaluating forecast accuracy. In Working Paper. homepage.univie.ac.at/robert.kunst/procip.pdf.

Zhou, Y. 2014. Modeling the joint dynamics of risk-neutral stock index and bond yield volatilities. Journal of Banking and Finance 38: 216-228. doi: 10.1016/j.jbankfin.2013.10.010. 